\title{
A Radiologia, o Radiologista e as demais especialidades
}

André Scatigno Neto

Diretor do Serviço de Radiologia do Instituto de Radiologia do HC-FMUSP

A Radiologia é uma especialidade médica que se renova e avança a cada dia, num processo de modernização que, além de investimentos, exige um esforço contínuo de atualização. Intrinsecamente ligados ao desenvolvimento tecnológico, os métodos diagnósticos por imagem possibilitam ao médico a obtenção de informações sequer imaginadas há menos de dez anos, com uma rapidez e eficiência que valorizam a Medicina como um todo.

Para que os especialistas da Radiologia e Diagnóstico por Imagem possam acompanhar a chegada de novas técnicas, seja em Radiologia Digital, Tomografia Computadorizada, Ultra-sonografia e Medicina Nuclear, o esforço é enorme, o que vem determinar o caminho da fragmentação e do afunilamento do conhecimento em subespecialidades cada vez mais restritas.

Se para o especialista que atua na área da imagem a necessidade de atualização é constante e se realiza num processo contínuo e que exige muita dedicação, através da participação em eventos, reuniões científicas e discussões de casos, para os colegas que atuam em outras áreas o conhecimento dessas novas técnicas se torna mais complexo e demanda um nível de exigência que poucos conseguem alcançar.

Talvez dessa situação resultem as inadequadas solicitações de exames que muitas vezes chegam aos serviços de imagem, que sabemos em nada contribuirão com o diagnóstico ou com o estabelecimento de propostas terapêuticas aos pacientes. Ainda assim devemos atender a essas requisições de exames, sob pena de incorrermos em infração ética.

$\mathrm{O}$ artigo 2 do Código de Ética Médica reza que "O alvo de toda a atenção do médico é a saúde do ser humano, em benefício da qual deverá agir com o máximo de zelo e o melhor de sua capacidade profissional".

Na interpretação do mestre Genival Veloso de França o "ato médico deve ser exercido de forma organizada e consciente, traduzido por técnicas, ações e recursos que tenham como meta a saúde do ser humano".

Dessa forma, os especialistas da Radiologia e Diagnóstico por Imagem devem ter uma participação ativa também na atenção básica à saúde, participar de reuniões multidisciplinares com as demais especialidades médicas, discutindo e divulgando os novos métodos de diagnóstico, permitindo a outros especialistas o conhecimento e a indicação do melhor exame para cada situação.

Ninguém melhor do que o médico radiologista para mostrar todo o potencial que os métodos diagnósticos por imagem trazem para a Medicina atual. Cabe a ele valorizar a tecnologia como instrumento a serviço do médico, para oferecer ao paciente o que há de melhor. 